\title{
Exploring higher education professionals' use of Twitter for learning
}

\author{
Muireann O’ Keeffe ${ }^{1}$ \\ Dublin City University, Dublin, Ireland \\ (Received October 2016; final version received October 2016)
}

\begin{abstract}
Twitter has become a hot topic of conversation in professional learning circles. However much of the commentary related to professional learning and Twitter is at best circumstantial rhetoric, which fails to illustrate the real experiences and complexities of professional learning in online spaces. This case study explored how eight higher education professionals engaged with Twitter for professional learning purposes. Data was collected and analysed from participant Twitter profiles and subsequent interviews explored professional learning on Twitter with participants.
\end{abstract}

Using the Visitor and Resident typology this paper highlights that participants were involved in a range of types of participation on Twitter. Participatory activities on Twitter were considered using Wenger's (1998) concepts of participation and non-participation. Although participants of this research supported Twitter for professional learning, this study indicates that professionals were hesitant to establish presence and participate in social networking activities via Twitter. Consequently, further research is needed to unpick the complexities of participation in online spaces.

\section{Introduction}

In recent years online social network sites (SNS) have become hot topics of conversation in professional learning circles (Hart, 2015). Indeed, claims that SNS such as Twitter support informal learning among higher education professionals have gained increasing attention (Beckingham, 2015; McPherson, Budge, \& Lemon, 2015).

Yet to date endorsement of open online spaces as places of learning for professionals is based on circumstantial and anecdotal evidence. Emerging social practices on SNS have been surprisingly under-researched and it is for this reason that that deep qualitative research to explore the uses and implications of using SNS professionally have been called for (Lupton, 2014; O'Keeffe, 2014; Veletsianos \& Navarrete, 2012). Furthermore, some criticisms exist that much of the emerging research on use of online social networks is situated among those who are positively disposed to online spaces and technologies (Skyring, 2013). Moreover, technology is frequently framed as having a benign presence in education (Selwyn, 2016) with others advocating for the uncritiqued benefits of using SNS for learning. Thus while there is much common rhetoric on how online social networks are transforming the functions of university life, alternative viewpoints about using social networks are

\footnotetext{
${ }^{1}$ Corresponding author. Email: muireann.okeeffe@dcu.ie
}

Irish Journal of Technology Enhanced Learning Ireland, 2014. C 2016 M. B. O’Keeffe. The Irish Journal of Technology Enhanced Learning Ireland is the journal of the Irish Learning Technology Association, an Irish-based professional and scholarly society and membership organisation. (CRO\# 520231) http://www.ilta.ie/. This is an Open Access article distributed under the terms of the Creative Commons Attribution 4.0 International License (http://creativecommons.org/licenses/by/4.0/), allowing third parties to copy and redistribute the material in any medium or format and to remix, transform, and build upon the material for any purpose, even commercially, provided the original work is properly cited and states its license. 
given limited attention. Therefore, it is timely to explore and capture how higher education professionals use Twitter for learning purposes.

This study, which describes findings from the first phase of completed Doctoral research, explores how higher education professionals (lecturers, academic developers, student support staff, and learning technologists) use Twitter for professional learning. The purpose of learning in this research is toward the enhancement and development of teaching and learning practices among those who teach and support teaching in higher education. This paper emphasises the informal and social features of professional learning and explores how one such SNS, Twitter, can potentially support professional learning. To this end, a case study approach was designed which investigated Twitter data of eight higher education professionals and followed up with interviews to explore how Twitter was being used for professional learning.

\section{Development of teaching and learning practices in higher education}

Teaching is viewed as a core and legitimate constituent of higher education work (Boyer, 1990; Boud $\&$ Brew, 2013) and in the last forty years activities to support and develop teaching practices within higher education have become more commonplace (Gibbs, 2013; Kandlbinder \& Peseta, 2009). While some describe the process of learning how to teach in higher education as an unsupported and isolating experience (Gourlay, 2011), continuing professional development (CPD) has become increasingly expected so that those with teaching duties can deepen their knowledge and skills and stay abreast of important developments for improvement in learning and teaching practices (Day \& Sachs, 2004; Eraut, 1994; Gibbs, 2013; National Forum, 2015).

Furthermore a variety of factors have increased the need for CPD including ensuring the quality of education (Gibbs, 2013), the emphasis on a student-centred approach to learning (Biggs \& Tang, 2007); and technological changes which broadened the scope of access to higher education. Thus, there is a need for higher education professionals to be learning professionals (Nixon, 2008) and higher education institutions should be involved in cultivating learning environments for professional development (Trevitt \& Perera, 2009).

\section{Professional learning}

Learning is at the heart of enhancing practice (Eraut, 1994) and is a key activity in developing professional values, codes and practices (Evans, 2008). Professional learning is acknowledged to occur informally and socially among professionals (Engeström, 2001; Eraut, 1994; Marsick \& Watkins, 1990; Wenger, 1998) and is crucial to enhancement of professional practice and performance at work (Eraut, 2004; Felstead, et al., 2004). Indeed, dialogue and collegial discourse among practitioners is said to be an important activity in the learning of teaching professionals (Palmer, 1998; Thomson, 2015; Wenger, 1998). To this end, searching for solutions to issues encountered in practice through involvement in professional communities has proven helpful for professionals (Heinrich, 2015; Nussbaum-Beach \& Ritter Hall, 2012; Pataraia et al., 2015) and learning from other educators and extending to outer networks beyond immediately available peers enables 'informal support from people on the spot' (McNally, 2006, p. 82).

\section{Informal learning}

So it seems that learning for professionals is not confined to engagement in formal educational or specialist training and is often unplanned (Dochy et al., 2011; Eraut, 2004; Mårtensson \& Roxå, 2015; Rienties \& Hosein, 2015). Rather, professional learning about practice takes place through collaboration where practitioners work together, share knowledge, and engage in cooperative inquiry 
to instigate change and growth as professionals (Dochy et al., 2011; Eraut, 1994; Wenger, 1998). Additionally, deep-seated motivation is important for professionals to develop themselves and pursue collaboration and cooperation amongst colleagues (Day \& Sachs, 2004; Eraut, 2004).

Informal learning events are important development opportunities for higher education staff (Gibbs, 2013; Mårtensson \& Roxå, 2015). Peer-professional discussion, joint problem solving, and opportunities that offer professionals a chance to engage in networks, partnerships and learning communities can offer occasions of reflection and learning on practice, in turn enhancing learning about teaching practice (Gibbs, 2013; Loads \& Campbell, 2015; Lunt, 2008; Pataraia et al., 2015; Sharpe, 2004). Also in current times where resources in higher education are tight and staff are timepoor, new flexible and informal opportunities for professional development are needed (Hunt, 2011; National Forum, 2015; Slowey, Kozina, \& Tan, 2014; Trevitt \& Perera, 2009). At the same time, the National Forum recognises that informal learning development opportunities play a significant part in developing the practices of those who teach and support teaching in higher education (National Forum, 2016).

\section{Social learning and personal learning networks}

Co-construction of knowledge occurs within relationships between people (Lave \& Wenger, 1991) and can influence practice and knowledge and ultimately become embedded in practice. While learning is regarded as a social practice, it is also dependent on the context and situation of the learning and much learning occurs with peers in workplace or professional settings (Billett, 2006; Eraut, 2004; Marsick \& Watkins, 1990). Furthermore learning about teaching has been acknowledged to occur in community settings (Hollins-Alexander, 2013; Hughes, 2007; Mårtensson \& Roxå, 2015; O'Keeffe, Cashman, \& O'Regan, 2008), providing linkages to wider circuits of knowledge and experts (Nerland \& Jensen, 2014), and enabling collaboration and effective opportunities to learn from others. Moreover, recent studies have highlighted that personal networks offer opportunities to interact with pools of knowledge concerning teaching influencing practice (Pataraia et al., 2015).

\section{Learning through participation in communities}

Social energy combined with opportunities for engagement situated in solving problems of practice contributes to learning (Wenger, 1998). Through practice, members of the community establish "what it is to be a competent participant, an outsider, or somewhere in between" (Wenger, 1998, p. 137). Wenger's concepts of participation and reification illustrate that participation enables the negotiation of meaning, turning experience into "thingness" (Wenger, 1998), learning becomes visible and tangible, in turn enabling the discernible communication of ideas and artefacts. This is apparent in online social spaces where participants reify meaning in online expressions through tweets, blogs, and other virtual artefacts (Bell, 2014).

\section{Online social networks for learning}

In the last decade, with the rise of the social web, there has been much discussion about how online social networks contribute to expanding opportunities for informal and social learning (Gee, 2005; Ito, et al., 2013; Seely Brown \& Thomas, 2011; Siemens, 2006). Some argue that the participatory web (Costa, 2014) expands the capacity to learn from greater audiences by offering access to information and to knowledge communities that can be harnessed anywhere, at anytime, and by anyone with Internet access (Ito, et al., 2013; Johnson et al., 2015). Indeed, some studies indicate that learners enjoy and appreciate the social learning experience afforded by online social networks (Veletsianos \& Navarrete, 2012) while others assert that personal learning environments (PLEs), supported by social media, can potentially marry formal and informal learning (Dabbagha \& Kitsantas, 2012). 
Furthermore, Cook \& Santos (2014) assert that SNS, used in well-designed ways, can support informal learning. Additionally, Jenkins, Ito, \& boyd (2015) reported on findings from a large-scale longitudinal study arguing that SNS support participatory practices, enabling creative and selfdirected learning. Similarly, Ito et al. (2013) in their framework of connected learning portrayed youths motivated to seek out mentorship in online spaces to satisfy their learning needs. So it seems that twenty-first century networking technologies can facilitate and stimulate online communities providing environments for sharing knowledge and practice leading to learning.

Nonetheless, some writers exercise caution indicating the over-emphasis and exaggerated benefits of technology for learning (Oliver, 2012; Selwyn \& Facer, 2013). Also some question the radical claims of openness offered by social online technologies as reinforcing idealistic thinking (Gourlay, 2015) while others argue that claims about SNS use are predominantly for impression management and political gain (Rheingold, 2010; Selwyn, 2012) rather than for open and democratic scholarly practices (Veletsianos, 2012).

\section{How is Twitter used for professional learning?}

Mainstream conversations about professional learning report Twitter as a top tool for learning (Hart, 2015). An American survey of faculty, reported Twitter as useful for learning (Gerstein, 2011) and Twitter has been proclaimed as a medium that can sustain professional learning for K-12 educators (Holmes, Preston, Shaw, \& Buchanan, 2013). In the higher education context Costa's (2014) research indicated that participation in online social networks potentially contributed to change in perspective and practices, thus contributing to learning for higher education scholars. Nonetheless, the research literature is scant on how Twitter is used for professional learning purposes among staff in higher education.

An investigation of studies existing on Twitter practices in academic life (Costa, 2013; Veletsianos \& Kimmons, 2012; Fransman, 2013; Ford, Veletsianos, \& Resta, 2014; Lupton, 2014) revealed that many studies in the higher education context to date focus on how scholars use Twitter to complement research duties. Indeed, networked participatory scholarship (Veletsianos \& Kimmons, 2012) describes how academics digitally disseminate "specialism in a field" (Weller, 2011, p. 5).

Veletsianos (2012) found that sharing of practice, of information and requesting assistance were among the social activities of academics on Twitter. Similarly, Lupton's (2014) research established that social networks helped academics to connect with other academics but urged for more research to move "beyond surveys and using qualitative research to produce thick descriptions of use" (Lupton, 2014, p. 32).

Finally, much of the existing literature investigating social networking use in higher education (Costa, 2013; Lupton, 2014, Veletsianos, 2012) has been broad-based in nature. To this end, this research, situated within an initial phase of a Doctoral study explores the topic of professional learning with those who teach and support teaching in higher education. A particular group of higher education professionals whom had completed a formal qualification in technology-enhanced learning were identified as using Twitter to extend their personal learning networks. Thus the aim of the remainder of this paper is to explore the activities of these higher education professionals on Twitter and to capture how these activities assist their professional development toward the functions of learning and teaching.

This aim is addressed by the following research questions:

1. What are the activities of higher education professionals using the social networking site Twitter?

2. How are activities on Twitter supporting the learning and development of these higher education professionals? 


\section{Methods}

Yin (2014) and Robson (2011) have noted that case study design is particularly suited to exploratory studies that asks 'how' and 'why' questions. Thus the case study design was chosen as it suited conditions of this research project allowing for in-depth study of phenomena in a fluid and iterative sense (Dowling \& Brown, 2010). Also the case study approach allowed the design to "emerge" (Robson, 2011) during data collection and analysis and to spot interesting insights not known prior to the initiative (Buchanan, 2012).

The eight participants were graduates of an academic development programme focussed on technology-enhanced learning. The participants had endeavoured to extend their personal learning networks beyond the formal walls of the classroom, into virtual spaces by using Twitter. Other selection criteria for this research required that they worked in the higher education sector and were using Twitter for professional learning purposes.

Ethical approval for this research was granted through the Institute of Education, University College London ethics review board. Furthermore, completion of the survey was entirely voluntary, with informed consent. Pseudonyms were used. While anonymity was pledged to participants it became apparent during analysis that Twitter data was searchable and identifiable. This ethical incident corresponded with challenges discussed by others pertaining to ethics and Internet research data (boyd \& Crawford, 2012; Markham \& Buchanan, 2012). Participants were notified about this potential risk to anonymity to which they responded, confirming they felt comfortable to proceed and be included in the research.

Twitter data was collected using Twitter Archiving Google Spreadsheets (TAGSExplorer ${ }^{2}$ version 5.110) and data collection was limited to the month of May 2014 (Bruns \& Stieglitz, 2014). Taking Veletsianos' (2012) study as a guide one hundred tweets per participant were downloaded. Data analysis of tweets got underway using Veletsianos' (2012) seven types of Twitter activity to accelerate the coding phase. However, some of Veletsianos' codes did not align with the data and became redundant and new codes were created. Also during analysis of tweets it became apparent that some participants had not tweeted during the time frame of the data collection. An investigation of Twitter profiles showed that one participant had never posted on Twitter while three participants had posted an inconsequential volume of tweets. Thus analysis of tweets for these participants was not possible. At this point the Visitor-Resident typology (White \& Le Cornu, 2011) was adopted to illustrate different modes of engagement among participants in the online space of Twitter.

Following this process interviews were organised to explore how activities on Twitter were influencing professional learning. Semi-structured interviews of all eight participants could gain rich data that could be sewn together to tell a story of the phenomena (Schostak, 2006). Interview participants were asked for their understanding of professional learning and how they perceived Twitter as helpful to professional learning.

Thematic analysis was used to analyse the interview data and Braun \& Clarke's (2006) six-phase guide identified themes in a systematic way. Leading from this the Twitter codes and the interview themes supported the development of case descriptions (Buchanan, 2012; Miles, Huberman, \& Saldana, 2014), which helped highlight findings in this study.

\section{Findings}

\footnotetext{
${ }^{2}$ TAGSexplorer is an application-programming interface (API) that collects data from Twitter. It downloads, organises Twitter data in bulk using a readable format. This software is free for educational use and developed by Hawksey (2013). See https://mashe.hawksey.info/2013/02/twitter-archive-tagsv5/.
} 
The Visitor and Resident continuum (Figure One) highlighted that participants had involved themselves in a spectrum of engagement on Twitter. Participants that demonstrated an absence of presence (Rourke et al., 2001) on Twitter were mapped to Visitor attributes (White \& Le Cornu, 2011) while those displaying more presence and participation on Twitter were matched with Resident attributes.

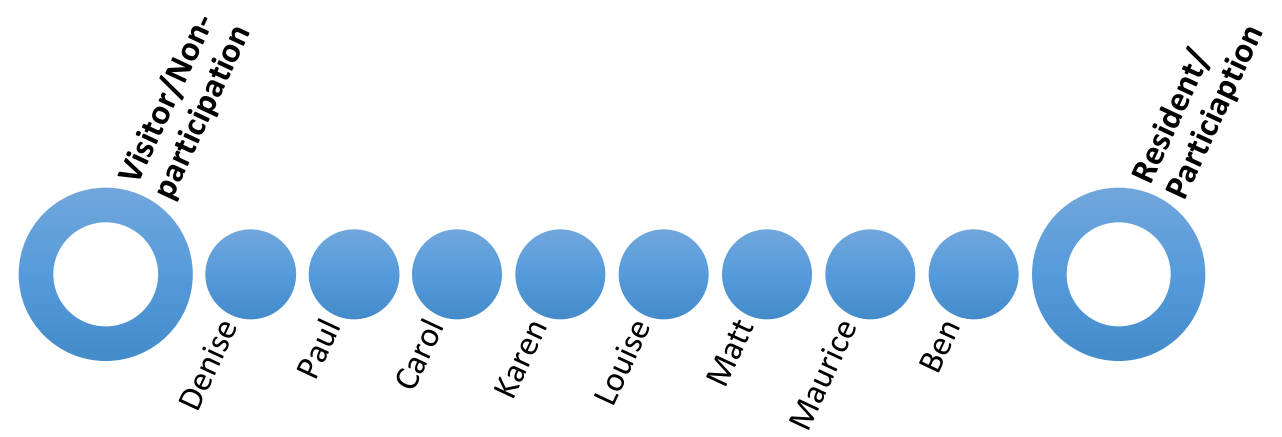

Figure 1 - Participant cases mapped to the Visitor-Resident continuum

While the Visitor-Resident mapping process was useful for highlighting similarities and differences in activities of participants on Twitter, Wenger's (1998) modes of participation was used to problematise various types of online participation. Non-participation or peripheral participation were matched with Visitor attributes while richer participation on Twitter matched with Resident attributes.

Rather than report on data from all cases, three of the eight participants are highlighted in this paper. These participants Denise, Louise, and Ben demonstrated various levels of engagement with Twitter and are presented here to show the significant differences in Twitter participation within the research cohort.

\section{Denise}

Denise, an experienced learning technologist, had never posted on Twitter, indicating an absence of social presence on Twitter at the time of data collection. Thus she was mapped to the Visitor end of the continuum. Conflictingly, she described professional learning as a social process of learning from more experienced colleagues:

"Those kind of undefined or ill-defined ways of interacting with colleagues who know a lot more than I do in an area and just watching what they do to understand the strategies they employ".

Professional learning for her was social and she participated in various face-to-face learning opportunities. The interview data revealed she found Twitter useful but did not want to post because she was:

"hypersensitive around putting thoughts and feelings online".

In the interview, Denise made it clear she did not want to make posts on Twitter at any time into the future. Nonetheless, Denise explained that Twitter was useful in gathering information from educational sources and she described how Twitter enabled the locating of resources and 
announcements from knowledgeable sources and organisations such as the $\mathrm{JISC}^{3}$ and the HEA ${ }^{4}$. While she followed other educators on Twitter she was cautious about initiating social contact with other tweeters, thus she refrained from posting tweets. For Denise Twitter was an informationgathering tool and she shunned the social network features offered by Twitter.

\section{Louise}

Louise, an early career learning technologist, described professional learning as learning from others and believed that Twitter was important to this process. She reported that Twitter helped her keep upto-date and indicated a perceived loss if Twitter ceased to exist:

\section{"It would leave a big hole. I can't see how you could continue to learn at the same rate without it".}

She described herself as a "lurker" strategically following educators, observing tweets, and gathering information to help with her work:

"It enabled me to do all the things you're meant to be able to do, to connect to the right people."

She considered how to apply new information from Twitter to practice and had created a toolkit of technologies from information retrieved via Twitter. She subsequently implemented this toolkit in eLearning design work. While the data showed she engaged in some Twitter discussions (Figure Two), Louise expressed her preference to observe and gather new information.

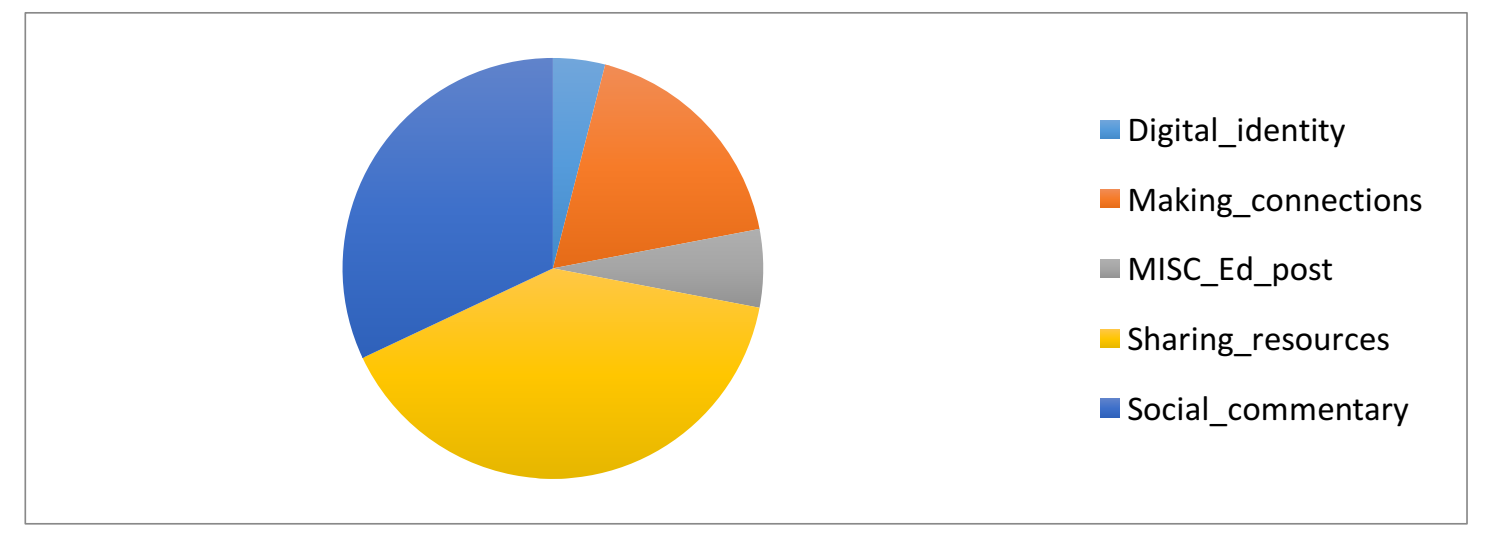

Figure 2- Louise's Twitter activities

She primarily used Twitter to retrieve information from other professionals in the area. Louise regarded herself as an observer on Twitter indicating she was not fully comfortable in expressing her voice online, however, contrastingly her tweets show that she established participation by making posts, establishing presence and involving herself in conversations. Further research is needed to tease out the reasons for Louise's preference for observing rather than participating and also to gain insight into Denise's feeling of uneasiness in posting knowledge or opinion via Twitter.

\footnotetext{
${ }^{3}$ Joint Information Systems Committee (JISC): An organisation in the United Kingdom providing leadership in the use of information and communications technology in learning, teaching, research and administration. Retrieved from https://www.jisc.ac.uk.

${ }^{4}$ The Higher Education Authority (HEA) leads the strategic development of the Irish higher education and research. Retrieved from http://www.hea.ie.
} 


\section{Ben}

Ben, a lecturer, discussed informal social learning opportunities as enabling his professional learning. Hearing viewpoints of professionals from other academic disciplines was essential to learning:

“...the coffee room is a great place for [learning] as well because we're on like a three school campus we actually meet people that are from different areas, and they would see things with a different perspective, views, and teach in different ways and I find that's a great way to learn as well, just to bounce ideas off them, listen to their conversations and seeing what they're doing in their class that I can try and apply".

Informal conversations inspired him to think about adopting new approaches and experiment with teaching practices. Opportunities for listening, sharing ideas, reflecting, and brainstorming with others were important. Similarly, Twitter helped him tap into new information and connect socially with others.

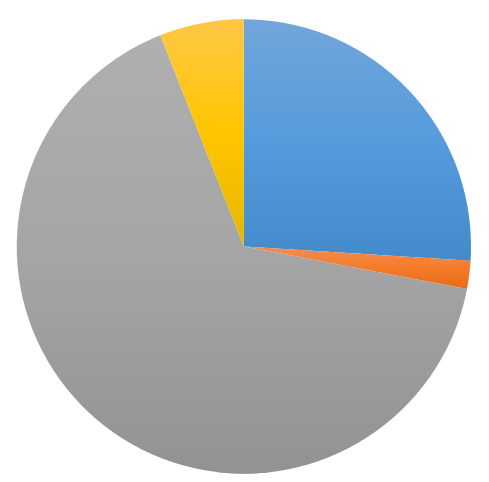

making_connections

- MISC_Ed_post

- Sharing_resources

Social_commentary

Figure 3- Ben's activities on Twitter

Ben perceived and used Twitter differently to Denise and Louise; he highlighted Twitter as valuable for collaborating and making links with other educators teaching in higher education.

There's a chemist, X[Person], over in X[Place]. She was kind of tweeting a good bit last year about her X[Project], that's the name of her project ... I made a connection with her.

Ben gave examples of establishing teaching and learning collaborations with educators in other universities via Twitter, which in turn contributed to changes in pedagogical practice and enabled peer forms of learning among his students. Ben described feeling comfortable in participating in social network activities on Twitter and gave examples of how collaborations initiated on Twitter contributed to innovation in pedagogical practice.

Data from three participants highlighted here have provided rich insights into understandings of professional learning and uses of Twitter for professional learning.

Denise's data exemplifies Twitter engagement of those situated on the Visitor end of the continuum whereby Twitter was used a tool to gather professionally relevant information. Furthermore Ben represents those demonstrating similar Resident activities of online engagement, social communication, and development of collaboration with other educators. Louise was hesitant to explicitly participate but nonetheless had established social presence on Twitter. The data of three participants highlighted here indicate the variety of types of engagement with Twitter that require further investigation and explanation. 


\section{Discussion}

Earlier it was noted that professional learning is largely a social and informal process (Eraut, 1994, Marsick \& Watkins, 1990; Wenger, 1998) and in this study when asked about professional learning, all participants described the vital social and informal nature of learning from other professionals. However, what was most interesting about the data was that while social learning was strongly advocated by all participants, social presence and participation on Twitter differed among the research participants. Participants with Visitor attributes preferred to read and gather information on Twitter and avoided using the social networking features of Twitter to connect or interact with others online, thus positioning themselves at the margins of communities on Twitter.

Much of the literature associated with online, informal or professional learning refer to learning as social and collaborative (Eraut, 1994; Gee, 2005; Ito, et al., 2013; Siemens, 2006). However, despite opportunities presented by Twitter for social modes of learning, Denise and those with Visitor attributes commonly used Twitter as an online bulletin board which enabled them to read information useful to their practice needs but chose not to share their comments or opinions on Twitter. They expressed a preference for inhabiting peripheral spaces of Twitter, observing other peoples' activities at a safe distance. Indeed, Stewart's research asserts
"participation makes us visible to others who may not know us, and makes our opinions and perspectives visible to those who may know *us*" (Stewart, 2014, para. 9).

Thus, further discussion and thinking is required in relation to Denise's absence of presence and her choice to shun participation on Twitter.

Denise had made a firm decision not to participate or establish presence on Twitter. Louise, however, while she regarded herself as a "lurker" on Twitter, showed that she established presence and made connections with other educators via Twitter. Ben was unmistakably more social on Twitter than other participants and had established collaborations with other universities, which had impacted on pedagogical practices, showing that Twitter was contributing to development of teaching and learning practices.

However, while there were differences in levels of sociality among participants it can be said that learning was accomplished by all participants. Indeed, data in this study demonstrates that peripheral participation (Lave \& Wenger, 1991) was useful to learning about practice for these participants. Additionally Jenkins, Ito, \& boyd's (2015) ideas on participatory learning echo this interpretation:

At any given moment there are many different modes of engagement: some are
watching and observing, waiting to participate, while others are on the floor
dancing and others are much more peripheral watching from the balcony
(Jenkins, Ito, \& boyd, 2015, p. 6)

By positioning themselves at the margins of Twitter spaces, participants of this study were enriching their professional knowledge and practices by visiting Twitter "for immersion and broader exposure" (Wenger, 1998, p. 122) to new knowledge.

Nonetheless, Wenger (1998) cautions against peripheral modes of participation that involve acquisition alone and forgo interactions with others in communities or networked spaces. He claims that "information does not build up to an identity of participation, it remains alien, literal, fragmented, unnegotiable" (Wenger, 1998, p. 219). Additionally the core properties of the connected learning framework include production-centred outcomes for learning (Ito, et al., 2013), where the products of learning are tokens of meaning and practice. However, in this study some participants chose not to post on Twitter, thus they avoided potentially testing the validity of their knowledge on Twitter. Through explicit tweeting of thoughts or opinions Visitor participants might have reified their 
knowledge about practice and initiated opportunity for further conversation on Twitter. Moreover, choosing not to post on Twitter became a barrier to establishing conversation with others that might have led to the negotiation of meaning, which in turn, may have enhanced their understanding and learning.

On the other hand, Ben tweeted, thereby exhibiting his knowledge and practice. He participated more centrally in communities, having conversations on Twitter. Ben found information about new pedagogical approaches via Twitter and initiated collaborations with others interested in this pedagogical strategy. He subsequently contributed knowledge back to the community through a journal article on the topic. So it can be said that, for Ben, tweeting about teaching and learning practices, led to collaboration and other opportunities. He was invited to write journal articles, blog posts and make presentations at conferences, thus extending learning and construction of knowledge.

Overall, in this small-scale study, it seems that Twitter was useful for professional learning which links to other findings that describe personal networks as beneficial for developing teaching and learning practices (Pataraia et al., 2010).

\section{Conclusion}

This sample of participants is small, so findings may not be generalisable to other contexts but yet provides rich data to reflect on and inspire further questions about how Twitter is used for learning by practitioners in higher education. Further research is necessary to tease out answers and reasons pertaining to preferences of some research participants for non-participation or peripheral participation on Twitter.

Other studies show the respect that educators have for Twitter (Holmes et al., 2013) in enabling informal and social learning. They indicate positive and endorsing perspectives of using Twitter for professional learning purposes. Indeed, this research makes a case for using Twitter for professional learning and that peripheral participation as well as highly social participation can be valuable for developing learning and teaching practices of higher education staff. Nevertheless, this study highlights hesitancy expressed by two participants in posting to the open online space of Twitter, therefore it is essential that further research explore the reasons behind decisions not to establish presence or participation on Twitter. The next phase of this Doctoral research will explore and problematise more thoroughly the barriers, enablers, and implications of using Twitter for professional learning purposes.

\section{References}

Beckingham, S. (2015). Social media for learning. Retrieved September 2015, from Social media for learning: http://socialmediaforlearning.com/

Bell, F. (2014). You can't have one without the other. Retrieved March 6, 2016, from Home at last: http://francesbell.com/tag/reification/

Bennett, E. (2012). A Four-Part Model of Informal Learning: Extending Schugurensky ${ }^{\text {ee }}$ s Conceptual Model . Retrieved June 2015, from Adult Education Research Conference (AERC) http://newprairiepress.org/aerc/2012/papers/3/

Billett, S. (2006). Constituting the workplace curriculum. Journal of Curriculum Studies, 38(1), 3148.

boyd, d., \& Crawford, K. (2012). Critical questions for big data. Information, Communication \& Society, 15(5), 662-679. 
Boud, D., \& Brew, A. (2013). Reconceptualising academic work as professional practice: implications for academic development. International Journal for Academic Development, 18(3), 208-221

Boyer, E. L. (1990). Scholarship reconsidered: Priorities of the professoriate. Princeton, N.J: Carnegie Foundation for the Advancement of Teaching.

Braun, V., \& Clarke, V. (2006). Using Thematic Analysis in Psychology. Qualitative Research in Psychology, 3(2), 77-101.

Bruns, A., \& Stieglitz, S. (2014). Quantitative approaches to comparing communication patterns on twitter. In K. Bredl, J. Hunniger, \& L. Jakob, Methods for analyzing social media (pp. 20-44). London: Routledge.

Buchanan, D. (2012). Case studies in organisational research. In G. Symon, \& C.

Chalmers, D. (2011). Progress and challenges to the recognition and reward of the Scholarship of Teaching in higher education. Higher Education Research \& Development, 30(1), 25-38.

Cook, J., \& Santos, P. (2014). Social network innovation in the internet's global coffeehouses: Designing a mobile help seeking tool in learning layers. Educational Media International, 51(3), 199213.

Costa, C. (2013). The habitus of digital scholars. Research in Learning Technology, 21(21274).

Costa , C. (2014). The web and the academic divide. Retrieved Nov 30, 2014, from Social Theory Applied: http://socialtheoryapplied.com/2014/04/28/web-academic- divide/

Dabbagha, N., \& Kitsantas, A. (2012). Personal learning environments, social media, and selfregulated learning: A natural formula for connecting formal and informal learning. The Internet and Higher Education, 15(1), 3-8.

Day, C., \& Sachs, J. (2004). Professionalism, performativity and empowerment: discourses in the politics, policies and purposes of continuing professional development. In C. Day, \& J. Sachs (Eds.), International Handbook on the Continuing Professional Development of Teachers. Berkshire: Open University Press.

Dochy, F., Gijbels, D, Segers, M., \& Van den Bossche, P. (2011). Theories of Learning for the Workplace: Building Blocks for Training and professional development programs. Oxon: Routledge.

Engeström, Y. (2001). Expansive Learning at work: Toward an activity theoretical reconceptualization. Journal of Education and Work, 14(1), 133-156.

Eraut, M. (1994). Developing professional knowledge and competence. Oxon: Routledge.

Eraut, M. (2004). Informal learning in the workplace. Studies in Continuing Education, 26(2), 247273.

Evans, L. (2008). Professionalism, professionality and the development of education professionals. British Journal of Educational Studies, 56(1), 20-38. 
Felstead, A., Fuller, A., Unwin, L., Ashton, D., Butler, P., Lee, T., \& Wal, S. (2004). Exposing learning at work: results from a recent survey. Retrieved August 2015, from Teaching and Learning Research Programme: http://www.tlrp.org/dspace/retrieve/450/WES2004.pdf

Ferreday, D., \& Hodgson, V. (2008). The tyranny of participation and collaboration in networked learning. Proceedings of the 6th International Conference on Networked Learning (pp. 640-647). Lancaster, UK: Lancaster University.

Ford, K., Veletsianos, G., \& Resta, P. (2014). The structure and characteristics of \#PhDChat, and emergent online social network. Journal of Interactive Media in Education, 8.

Fransman, J. (2013). Researching academic literacy practices around Twitter: performative methods and their onto-ethical implications. In R. Goodfellow , \& M. Lea, Literacy in the Digital University: Critical Perspectives on Learning, Scholarship, and Technology (pp. 27-41). London: Routledge.

Gee, J. P. (2005). Semiotic social spaces and affinity spaces: From the age of mythology to today's schools. In D. Barton, \& K. Tusting, Beyond Communities of practice: Language, power, and social context (pp. 214 - 232). New York: Cambridge University Press.

Gerstein, J. (2011). The Use of Twitter for Professional Growth and Development. International Journal on E-Learning, 10(3), 273-276.

Gibbs, G. (2013). Reflections on the changing nature of educational development. International Journal for Academic Development, 18(1), 4-14.

Gourlay, L. (2011). New lecturers and the myth of 'communities of practice'. Studies in Continuing Education, 33(1), 67-77.

Gourlay, L. (2015). Open education as a 'heterotopia of desire'. Learning, Media and Technology, 40(3), 310-327.

Hart, J. (2015). Twitter for Learning: The Past, Present and Future. Retrieved April 20, 2015, from Learning in the Social Workplace: http://www.c4lpt.co.uk/blog/2015/03/31/twitter-for-learning-thepast- present-and-future/

Hawksey, M. (2013, Feb 15). Twitter Archiving Google Spreadsheet TAGS v5. Retrieved from The Musing of Martin Hawksey (EdTech Explorer): https://mashe.hawksey.info/2013/02/twitter-archive$\underline{\operatorname{tagsv} 5 /}$

Hayes, E., \& Gee, J. (2010). Popular culture as a public pedagogy. Retrieved Sept 29, 2015, from jamespaulgee.com: http://jamespaulgee.com/admin/Images/pdfs/Popular Culture and\%2 0Public Pedagogy.pdf

Heinrich, E. (2015). Identifying teaching groups as a basis for academic development. Higher Education Research \& Development, 34(5), 899-913.

Holmes, K., Preston, G., Shaw, K., \& Buchanan, R. (2013, August). 'Follow' Me: Networked Professional Learning for Teachers. Australian Journal of Teacher Education, 38(12). Retrieved April 20, 2015, from EduResearch Matters: http://www.aare.edu.au/blog/?p=564

Hunt, C. (2011). National Strategy for Higher Education to 2030 - Report of the Strategy Group. Dublin: Department of Education and Skills. 
Ito, M., Gutiérrez, K., Livingstone, S., Penuel, B., Rhodes, J., Salen, K.,Watkins, C. (2013). Connected learning: an agenda for research and design. Irvine, CA, USA: Digital Media and Learning Research Hub.

Jenkins, H., Ito, M., \& boyd , d. (2015). Participatory Culture in a Networked Era: A Conversation on Youth, Learning, Commerce, and Politics. Cambridge: Polity Press.

Johnson, L., Becker, S., Cummins, M., Estrada, V., \& Freeman, A. (2015). NMC Technology Outlook for Higher Education in Ireland: A Horizon Project Regional Report. The New Media Consortium, ILTA. Austin, Texas: The New Media Consortium.

Kandlbinder, P., \& Peseta, T. (2009). Key concepts in postgraduate certificates in higher education teaching and learning in Australasia and the United Kingdom. International Journal for Academic Development, 14(1), 19-31.

Lave, J., \& Wenger, E. (1991). Situated Learning: legitimate peripheral participation. Cambridge: Cambridge University Press.

Loads, D., \& Campbell, F. (2015). Fresh thinking about academic development: authentic, transformative, disruptive? International Journal for Academic Development, 20(4), 355-369.

Lunt, I. (2008). Ethical issues in professional life. In B. Cunningham (Ed.), Exploring Professionalism (pp. 73-98). London: Bedford Way Papers.

Lupton, D. (2014). 'Feeling Better Connected': Academics' Use of Social Media. News \& Media Research Centre, University of Canberra. Canberra: University of Canberra.

Markham, A., \& Buchanan, E. (2012). Ethical decision-making and Internet research:

Recommendations from the AoIR ethics working committee (Version 2.0).

Marsick, V., \& Watkins, K. (1990). Informal and incidental learning in the workplace. London and New York: Routledge.

Mårtensson, K., \& Roxå, T. (2015). Academic development in a world of informal learning about teaching and student learning. International Journal for Academic Development, 20(2), 109-112.

McConnell, D., Hodgson, V., \& Dirckinck-Holmfeld, L. (2012). Networked learning: A brief history and new trends. In L. Dirckinck-Holmfeld, V. Hodgson, \& D. McConnell, Exploring the Theory, Pedagogy and Practice of Networked Learning (pp. 3-24). New York: Springer.

McNally, J. (2006). From informal learning to identity formation: a conceptual journey in early teacher development. Retrieved Nov 2015, from Scottish Educational Review:

http://www.ser.stir.ac.uk/pdf/227.pdf

McPherson, M., Budge, K., \& Lemon, N. (2015). New practices in doing academic development: Twitter as an informal learning space. International Journal for Academic Development, 20(2), 126136.

Miles, M., Huberman, A., \& Saldana, J. (2014). Qualitative Data Analysis A Methods Sourcebook (3rd ed.). Thousand Oaks, London: Sage. 
Nerland, M., \& Jensen, K. (2014). Learning through epistemic practices in professional work. In T. Fenwick, \& M. Nerland, Reconceptualising Professional Learning. Sociomaterial knowledges, practices and responsibilities (pp. 24-37). London \& New York: Routledge.

National Forum. (2015). Mapping Professional Development Pathway for those who Teach in Irish Higher Education: Where are we now and where do we want to go? National Forum for the Enhancement of Teaching and Learning in Higher Education. Dublin.

National Forum. (2016). National Professional Development Framework for All Staff Who Teach in Higher Education. National Forum for the Enhancement of Teaching and Learning in Higher Education. Dublin. Retrieved http://www.teachingandlearning.ie/wp-content/uploads/2016/09/PDFramework-FINAL-1.pdf

Nixon, J. (2008). Towards the Virtuous University: The Moral Bases of Academic Practice. New York: Routledge.

Nussbaum-Beach, S., \& Ritter Hall, L. (2012). The Connected Educator: Learning and Leading in a Digital Age. Bloomington, IN: Solution Tree Press.

O'Keeffe, M. (2014). Exploring the continued professional development of higher education professionals as they participate in online social spaces. British Education Studies Association. Glasgow.

O'Keeffe, M., Cashman, D., \& O'Regan, L. (2008). Supporting the development of communities of practice: informal versus formal communities. ALT-C conference. Leeds, UK: ALT.

Oliver, M. (2012). Technology and change in academic practice. In P. Trowler, M. Saunders, \& V. Bamber, Tribes and Territories in the 21 st Century Rethinking the significance of disciplines in higher education (pp. 220-231). London: Routledge.

Palmer, P. (1998). The Courage to Teach: Exploring the Inner Landscape of a Teacher's Life. San Francisco: Jossey-Bass.

Pataraia, N., Margaryan, A., Falconer, I., \& Littlejohn, A. (2015). How and what do academics learn through their personal networks? Journal of Further and Higher Education, 39(3), 336-357.

Rheingold, H. (2010). Attention, and Other 21st-Century Social Media Literacies. EDUCAUSE Review, 45(5), 14-24. Retrieved from EDUCAUSE Review.

Rienties, B., \& Hosein, A. (2015). Unpacking (in)formal learning in an academic development programme: a mixed-method social network perspective. International Journal for Academic Development, 20(2), 163-177.

Robson, C. (2011). Real World Research (3rd ed.). Chichester: John Wiley \& Sons.

Rourke, L., Anderson, T., Garrison, D., \& Archer, W. (2001). Assessing Social Presence In Asynchronous Text-based Computer Conferencing. Journal of Distance Education, 14(3), 51-70.

Schostak, J. (2006). Interviewing and representation in qualitative research. Berkshire: Open university press.

Seely Brown, J., Thomas, D. (2011). A New Culture of Learning: Cultivating the Imagination for a World of Constant Change. Charleston: Createspace. 
Selwyn, N, N., \& Facer, K. (2013). Introduction the need for a politics of education and technology. In N. N. Selwyn, \& K. Facer, The Politics of Education and Technology Conflicts, Controversies, and Connections (pp. 1-17). New York: Palgrave Macmillan.

Selwyn, N. (2012). Ten suggestions for improving academic research in education and technology. Learning, Media and Technology, 37(3), 213-219.

Selwyn, N. (2016) Digital downsides: exploring university students' negative engagements with digital technology, Teaching in Higher Education.

Sharpe, R. (2004). How do professionals learn and develop? Implications for staff and educational developers. In D. Baume, \& P. Kahn, Enhancing Staff and Educational Development (p. 132).

Siemens, G. (2006). Connectivism: Learning Theory or Pastime for the Self-Amused? Retrieved April 30, 2015, from elearnspace everything eLearning: http://www.elearnspace.org/Articles/connectivism_self-amused.htm

Skyring, C. (2013). Learning in 140 characters: Microblogging for Professional Learning. Thesis, Queensland University of Technology, Faculty of Education, Brisbane. Retrieved May 20, 2015, from http://eprints.qut.edu.au/65854/1/Carol Skyring Thesis.pdf

Slowey, M., Kozina, E., \& Tan, E. (2014). Voices of academics in Irish Higher education. Perspectives on professional development. Dublin: AISHE.

Stewart, B. (2014). Networks of Care and Vulnerability. Retrieved May 10, 2015, from the theoryblog: http://theory.cribchronicles.com/2014/11/04/networks-of- care-and-vulnerability/

Thomson, K. (2015). Informal conversations about teaching and their relationship to a formal development program: learning opportunities for novice and mid- career academics. International Journal for Academic Development, 20(2), 137- 149.

Trevitt, C., \& Perera, C. (2009). Self and continuing professional learning development: issues of curriculum and identity in developing academic practice. Teaching in Higher Education, 14(4).

Veletsianos, G. (2012). Higher education scholars' participation and practices on Twitter. Journal of Computer Assisted Learning, 28(4), 336-349.

Veletsianos, G., \& Kimmons, R. (2012). Networked participatory scholarship: Emergent technocultural pressures toward open and digital scholarship in online networks. Computers \& Education, 58(2), 766-774.

Veletsianos, G. \& Navarrete, C. (2012). Online Social Networks as Formal Learning Environments: Learner Experiences and Activities. The International Review Of Research In Open And Distance Learning, 13(1), 144-166.

Weller, M. (2011). The Digital Scholar How Technology Is Transforming Scholarly Practice. London: Bloomsbury Open Access.

Wenger, E. (1998). Communities of Practice: Learning, Meaning, and Identity. Cambridge: Cambridge University Press.

White, D., \& Le Cornu, A. (2011). Visitors and Residents: A new typology for online engagement. First Monday, 16(9). 
M. O'Keeffe

Yin, R. K. (2014). Case Study Research: Design and Methods (5 Ed.). California: Sage Publications. 